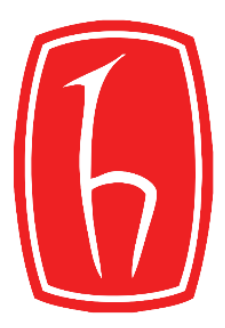

\author{
Hacettepe Üniversitesi Edebiyat Fakültesi Dergisi \\ Hacettepe University Journal of Faculty of Letters \\ Cilt/Volume: 35 Sayı/Number:2
}

Aralık/December 2018

doi: 10.32600/huefd.430113

\title{
Yeni Bir Disk Yüzlü Figürin ve Anadolu’da Tanrıça Tapınımı Kapsamında İncelenmesi
}

\author{
A New Disc-Faced Figurine and Its Examination Within the Scope of Goddess \\ Worship in Anatolia
}

Emre ERDAN*

\begin{abstract}
Öz
Disk yüzlü figürinler, İç Batı Anadolu’nun “İznik/Bitinya”, "Yukarı Sakarya”, "Demircihöyük”, "Kütahya”, “Afyon” ve "Kusura" gibi Erken Tunç Çağı II kültür bölgeleri ile ilişkili, sınırlı bir dağılım gösteren önemli arkeolojik eserler arasında yer almaktadır. Başlıca karakteristik özelliği disk biçiminde oluşturulmuş yüzleri ile tanınan figürinlerin kısıtlı bir bölgede, az sayıda örnekle temsil ediliyor olması önemlidir. Disk yüzlü figürinlerin, takip eden binyıllar içerisinde tanrıça ikonografisinde görülen polos ile betimlenmiş öncül örnekler olmaları da onları önemli kılan nitelikleri arasındadır. Disk yüzlü figürinler çoğunlukla oturur bir kadını betimlerler. Kısıtlı sayıda bazı örneklerde ise figürinlerin ayakta olduğu görülür. Çalışmamız içerisinde incelediğimiz disk yüzlü figürin Dr. Kemal Uğurbil'in özel koleksiyonunda yer almaktadır. Benzerleri arasında nadir görülen bazı özellikler sergileyen figürin, Erken Tunç Çağı II içlerine tarihlendiği düşünülmektedir.
\end{abstract}

Anahtar sözcükler: Disk yüzlü figürin, Erken Tunç Çağı, Tanrıça tapınımı, Polos.

\begin{abstract}
Disc-faced figurines are among the rare archaeological artefacts related to the Early Bronze Age II cultural regions in Inland Western Anatolia such as "İznik / Bitinya", "Upper Sakarya", "Demircihöyük", "Kütahya", "Afyon" and "Kusura". It is important that these figurines, known for their characteristic disc-shaped faces are represented in a restricted area with such few examples. What makes them important is the fact that the disc-faced figurines are the first examples depicted with the polos in the iconography of the goddess in the following millennia. Disc-faced figurines often depict a sitting woman. In a limited number of examples, figurines are seen as standing. Disc-faced figurine which we examined in this study is preserved in the private collection of Dr. Kemal Uğurbil. It is thought that the figurine that exhibits some rare characteristics among the others dates back to the Early Bronze Age II.
\end{abstract}

Keywords: Disk-faced figurine, Early Bronze Age, Goddess worship, Polos.

\footnotetext{
* Dr. Öğretim Üyesi, Adnan Menderes Üniversitesi, Fen-Edebiyat Fakültesi, Arkeoloji Bölümü, erdanemre@gmail.com.
} 


\section{Giriş}

$\mathrm{Bu}$ çalışmada, Dr. Kemal Uğurbil'e ait özel koleksiyonda yer alan ve İzmir Arkeoloji Müzesi tarafından 641 envanter numarası ile kayıtlanmış, terminolojide Disk Yüzlü/Scheibengesicht (Korfmann, 1979, s. 188) ya da Geçiş Bölgesi Figürinleri (Gündoğan Aydıngün, 2003, s. 82-83) olarak anılan tip grubuna giren pişmiş toprak bir figürin ele alınacaktır ${ }^{1}$. Benzerleri arasında az sayıda örnekte karş1laşılan duruş pozisyonundaki farklılıkla dikkati çeken figürin envanter kayıtlarına göre koleksiyona satın alma yoluyla 2015 yılında kazandırılmış olup, Uşak yöresinden getirildiği belirtilmektedir. Çalışmamız kapsamında değineceğimiz disk yüzlü figürini tanıtmadan önce, söz konusu özel tip figürin grubuna dair bilgilere kısaca yer vermenin faydalı olacağını düşünmekteyiz.

\section{Disk Yüzlü Figürinler}

Disk yüzlü figürinler, bugüne değin ele geçen örnekleri 1şığında kabaca İç Batı Anadolu'nun, daha çok kuzey kesimlerinde yer alan ve Erken Tunç Çağı'nda iskan edilen yerleşimlerine özgü, bu bölgenin Erken Tunç Çağ kültür grubu tarafından benimsenmiş olduğu düşünülebilen özel tür figürinlerdir. Disk yüzlü figürinler ile karşılaşılan coğrafya, Ay Efe tarafından Doğu Marmara kıyılarından, doğuda Sivrihisar Dağları'na ve güneyde Uşak ve Afyonkarahisar'1 içine alan bölge itibariyle değerlendirilmektedir (Ay Efe, 2006, s. 92). Disk yüzlü figürinler bugüne dek Bursa'da İnegöl (Korfmann, 1979, s. 187; Efe, 1992, s. 562), Bilecik’te Bozüyük (Körte, 1899, Lev. I ve Korfmann, 1979, s. 198; Bilgi, 1979, s. 134), Eskişehir'de Üryan Höyük (Korfmann, 1979, s. 199), Küllüoba (Ay Efe, 2006), Şarhöyük (Darga, Sivas ve Sivas, 2002, s. 210211), Demircihöyük (Korfmann, 1979, s. 199; Bilgi, 1979; Obladen Kauder, 1996, s. 261 vd), Yukar1 Sögütünü I (Efe, 1992, s. 562), Afyonkarahisar'da Manahoz (Korfmann, 1979, s. 200), Çıkrık (Korfmann, 1979, s. 200; Bilgi, 1979, s. 133-134; Aydıngün, 2006, s. 32; Bilgi, 2012, s. 298), Bavurdu (Korfmann, 1979, s. 197), Kaklık (Topbaş, Efe ve İlasl1, 1998, s. 66-67), Kusura (Korfmann, 1979, s. 199), Uşak'ta Banaz (Bilgi, 1979, s. 137; Gündoğan Aydıngün, 2003, s. 47), Kütahya'da Seyitömer (Silek, 2010, s. 4849) ve Çiledir (Türktüzün, Ünan ve Ünal, 2014, s. 58, 60), Manisa’da Akhisar Höyük (Ormerod, 1913, s. 54-56; Korfmann, 1979, s. 197) ile Isparta'da Nudra (Korfmann, 1979, s. 198) gibi merkezlerden elde edilen örnekler aracılığıyla bilinmektedir. Bu merkezlerin yanısıra, her ne kadar form açısından farklılıklar gösterse de, en azından yüz ve baş detayları ile disk yüzlü figürin örneklerinin benzerleriyle Kırklareli'nde yer alan Kanlıgeçit’te de rastlanıldığı bilinmektedir (Karul, 2005, s. 117-121). Doğrudan figürin olarak üretilen asıllarından farklı olarak, bu tip figürinlerin kap biçiminde formlandırılmış örnekleri de bulunmaktadır. Söz konusu ünik eserlerle bugüne değin sadece Bavurdu (Korfmann, 1979, s. 188), Höyüklü-Isparta (Bilgi, 2012, s. 309) ve Afyonkarahisar Müzesi'nde bir örnek (Bilgi, 2012, s. 309) ile karş1laşı1mıştır (Şekil 1).

Disk yüzlü figürinleri nispeten dar bir coğrafi alanda görülen bir figürin tipi olmaları dışında özel kılan başkaca ve daha önemli bir sebep de, söz konusu tip figürinlerin sergilediği, aynı dönemde çevre kültür bölgelerinde görülen figürin ve idol tiplerinden ayrı değerlendirilmelerini sağlayan biçemsel farklılıklardır. Anılan figürinlerin karakteristik stil özellikleri arasında disk şeklinde biçimlendirilmiş, dolgun yüz hatları, plastik şekillendirilmiş iri, kısmen uzun ve delikleri vurgulanmış burun, oval ya da badem formunda, oluk ya da içe gömülmüş gözler, bazı örneklerde küçük dikey oyuklarla zenginleştirilmiş fakat çoğu örnekte yalın bırakılmış ağız, yine bazı durumlarda delikli, bazen yalın, tekil bir örnekte ise açısal yivlerle belirtilen kulak ve başın arkasında yer alan polos sayılabilmektedir (Obladen Kauder, 1996, s. 261; Ay Efe, 2006, s. 92). Disk yüzlü figürinlerin sergilediği en önemli unsurlardan biri olarak dikkati çeken ve geç dönemlerde tanrıçanın "kent koruyucu" yönüyle ilişkilendirilen (Erdoğan, 2003, s. 93) polosların çoğunlukla yuvarlak ya da enine kesitli (Obladen Kauder, 1996, Taf. 121.3), düzleştirilmiş ve/veya hafifçe girintili (Obladen

\footnotetext{
${ }^{1}$ Koleksiyonunda yer alan eserler üzerinde çalışma izni veren Dr. Kemal Uğurbil'e teşekkürlerimi sunarım. Koleksiyonda yer alan ve Erken Tunç Çağ’a tarihlenen diğer eserler için bkz. Gür ve Erdan, 2018.
} 
Kauder, 1996, Taf. 120.6) örnekleri bulunmakta, az sayıda bazı örneklerde polosların delikli oldukları da bilinmektedir (Obladen Kauder, 1996, Taf. 121. 3).

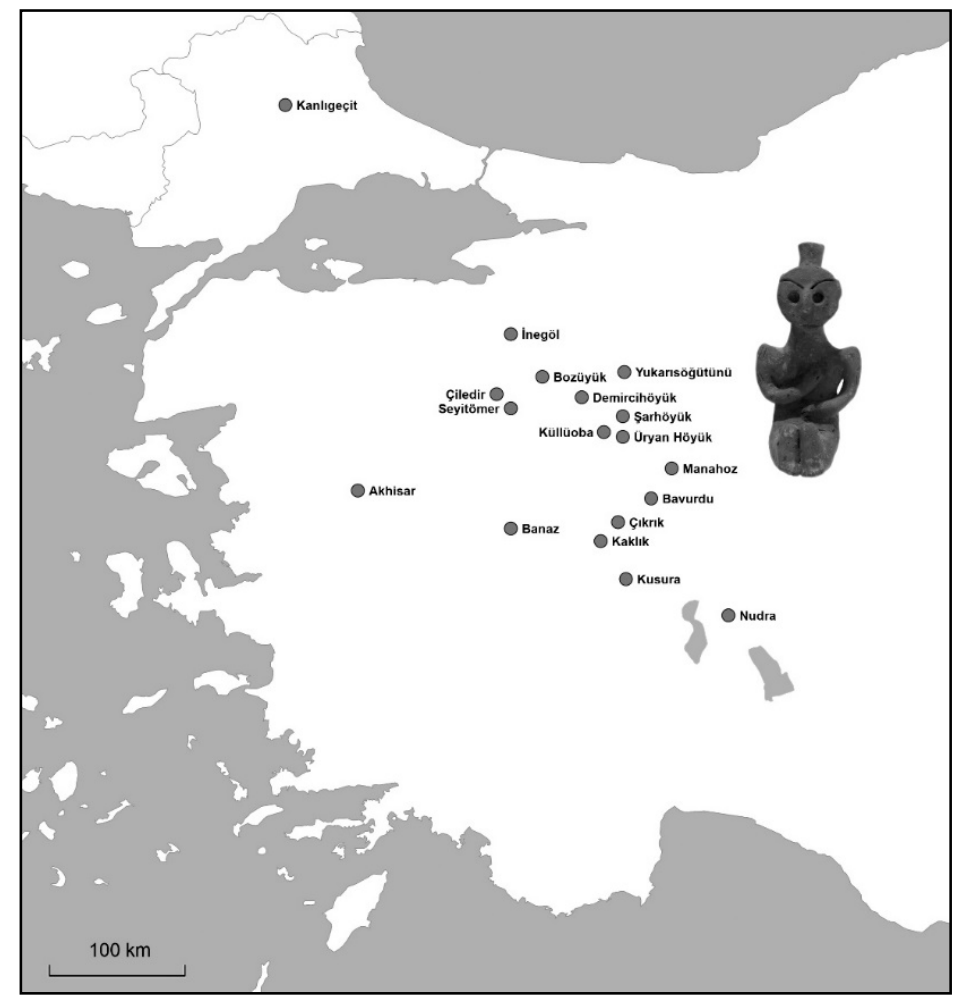

Şekil 1. Disk Yüzlü Figürinlerin Buluntu Noktalarını Gösterir Harita (stepmap.com'dan tarafımızca düzenlenmiştir.)

\section{Kemal Uğurbil Koleksiyonu'nda Yer Alan Disk Yüzlü Figürin}

Çalışmamızda değerlendirdiğimiz disk yüzlü figürin, pişmiş topraktan üretilmiş olup, kırmızı renktedir (10R5/8 Red). İlgili koleksiyonda, İzmir Arkeoloji Müzesi tarafından 641 envanter numarasi ile kayıtlanmış, Uşak yöresinden geldiği bildirilmiştir. Oturur şekilde betimlenen eser 12,4 cm. yüksekliğinde, $5,5 \mathrm{~cm}$. genişliğinde, benzer örneklerine oranla daha küçük yapıda olan figürinler arasında yer almaktadır (Şekil 2-3).

Figürinin disk şeklinde oluşturulmuş olan yüz kısmı 3,7 cm. uzunluğunda ve 3,5 cm. genişliğindedir ve yüzü kapsayan başın üst kısmında ince, $1,5 \mathrm{~cm}$. uzunluğunda bir polos yer almaktadır. Yüz yapısı, genişoval disk görünümündedir. Yüz kısmında ilk dikkati çeken geniş̧̧e oluşturulmuş alın kısmı ve alın ile göz arasında yer alan derin yivli, ince ve uzun dışa dönük kaşlardır. Kaşların hemen altında, aynı alet kullanılarak açılmış olduğu boyut birlikteliği açısından net olan iki göz çukuru bulunur. Göz çukurları, yüzün arka kısmında yer alan iri kulaktaki delikleri karşılar şekilde, paralel olarak oluşturulmuştur. Göz çukurlarının hemen altında iri, kavisli bir burun dikkati çeker. Sırt kısmında keskin bir dönüş yapan burnun kökünden ucuna kadar olan uzunluk neredeyse disk biçimli yüzün yarısını kapsar niteliktedir. Burnun altında yatay bir oluk ile belirtilen ağız kısmı yer almaktadır. Ağız kısmı içinde siyah boya kullanarak oluşturulmuş altı sıra dikine çizgi olasılıkla dişleri tanımlamaktadır. 


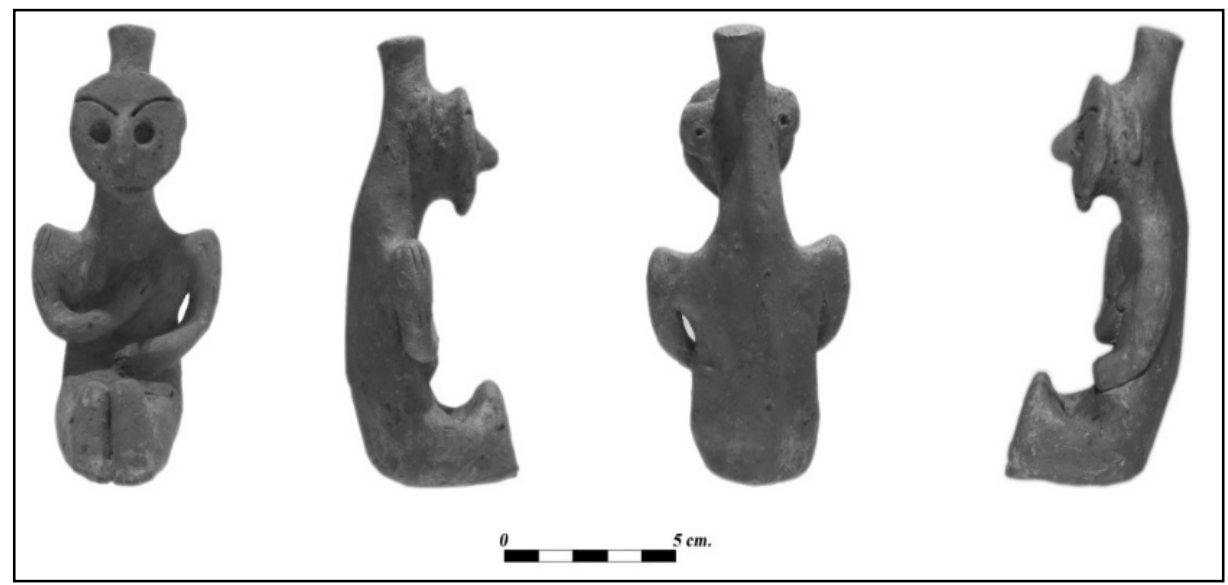

Şekil 2. Kemal Uğurbil Koleksiyonu’nda Yer Alan Disk Yüzlü Figürin. (Fotoğraf: Emre Erdan)

Kalın ve figürinin genel şablonuna oranla yüksek şekilde oluşturulmuş boyun, anatomi bilimi kapsamında üst akromion olarak tanımlanan uç kısımlarından yukarı sivriltilmiş dar omuzla bağlantıyı sağlar. Figürinin her iki omuz-kol birleşim, hem de kolların pazu kemiği olarak tanımlayabileceğimiz noktalarında, disk yüzlü figürinlerin bugüne değin bilinen bazı örneklerinden de tanınan dikine kazıma çizgiler yer almaktadır. Kollar dirsekten kırık, sağ kol gövdede oldukça küçük yapıda işlenen sol göğüs üzerinde, sol kol ise karın üzerinde betimlenmiştir. Ellerde parmak detayları ince yivlerle belirtilmiş, sol elin durduğu karnın hemen alt kısmında pubik bölge kare şeklinde, kazıma çizgilerle işlenmiştir. Gövdeyle hemen eşit boyutlarda oluşturulan geniş kalça kısmından kıvrılan bacaklar dizden karna çekilmiş, bacaklar birbirinden bir yivle ayrılmış, ayaklar karşıya bakar durumdadır. El detaylarında olduğu üzere ayak parmaklarında da parmak araları ince yivlerle betimlenmeye çalışılsa da, nitelikli bir görünüm yakalanamamıştır. Bunların yanı sıra figürinin belirgin özelliklerinden birisi de, sırt kısmında enseden başlayarak pelvise kadar uzanan omurganın hafif bir çıkıntı şeklinde belirtilmiş olmasıdır.

\section{Stil ve Tarihlendirme}

Daha önce değindiğimiz üzere, disk yüzlü figürinler ile daha çok İç Batı Anadolu'nun kuzey kesimlerinde karşılaşılmakta, bu figürin tipi bölgede yer alan Demircihöyük, Küllüoba, Çıkrık ve Kaklık gibi merkezler ışı̆̆ında tanınmaktadır.

Disk yüzlü figürinlerin Demircihöyük’te ele geçen örnekleri üzerinde kapsamlı bir inceleme gerçekleştiren Obladen Kauder, figürinlerin belirgin bir tipolojik gelişim sergilediklerini bildirmekte, gelişimi A-C arası üç grupta değerlendirmektedir. Buna göre disk yüzlü figürinlerin erken evresi sayılabilecek A Grubu figürinler profilde düz ve hafif yuvarlatılmış, yukarı doğru incelir yapıda şematize yuvarlak baş, oyuk gözler ve ince uzun kaşlarla betimlenmiştir. Bir sonraki aşama olan B Grubu figürinlerinde A Grubu'na dair özellikler devam etmekle birlikte, bu grubun aksine oval ve profilde oldukça keskin bir biçimde keskin olan başlar hafif sola eğik yapıda işlenmiştir. Çalışmamız kapsamında değerlendireceğimiz C Grubu örneklerinde baş kısımları iyice düzleştirilmiş, disk biçiminde yüz ve yüz ortasında belirgin burun, göz ve ağız kısımlarıyla bir arada oluşturulmuştur. Anılan C Grubu figürinler yine aynı çalışmada, yüz tipleri bakımından üç alt tipte incelenmekte, buna göre 1. Tip, yuvarlak-düz disk, 2. Tip, uzun-oval disk, 3. Tip ise geniş-oval disk şeklinde tanımlanmaktadır (Obladen Kauder, 1996, s. 261). 


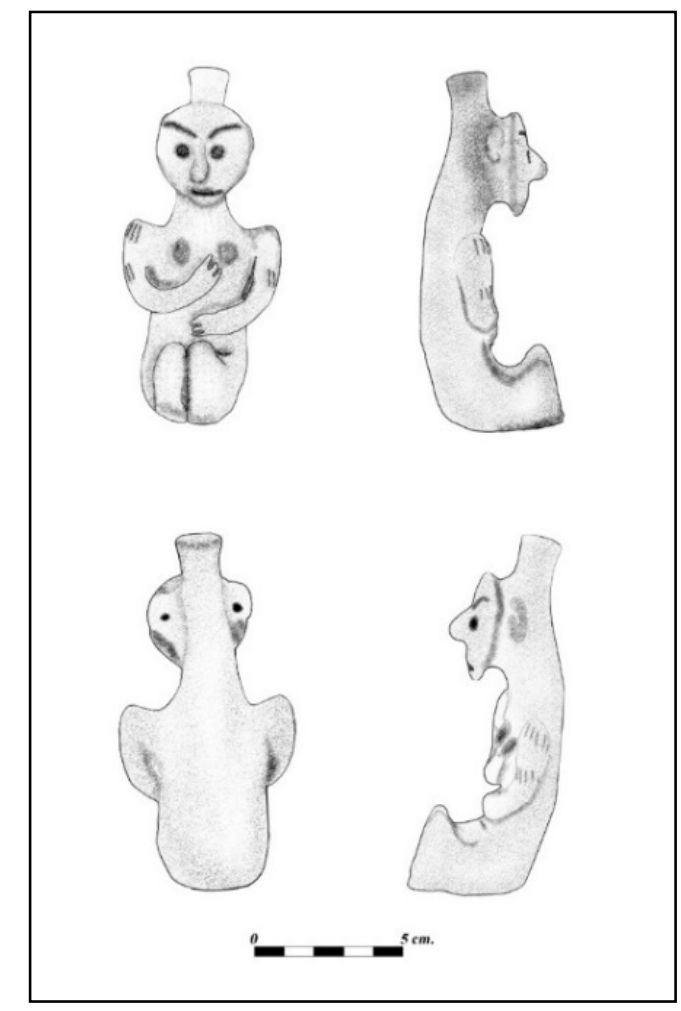

Şekil 3. Kemal Uğurbil Koleksiyonu’nda Yer Alan Disk Yüzlü Figürin. (Çizim: Emre Erdan)

Natüralist biçemde oluşturulduğu gözlemlenen figürinlerin gövde baş arasında geçişi yansıtan boyunları çoğunlukla kalın ve yüksek yapıdadır. Baş, yüz ve boyun detayları kısaca yukarıda değindiğimiz özellikleri sergileyen disk yüzlü figürinlerin büyük çoğunluğunun oturur pozisyonda oldukları bilinmekteyse de, buna karşın az sayıdaki örnekte ise ayakta belirtildikleri örnekler de bulunmaktadır (Ay Efe, 2006, s. 92). El ve ayak ayrıntılarının fazla önemsenmediği, parmak aralarının yivlerle betimlendiği figürinlerin kol, bacak, gögüs ve kalçalarının vurgulu bir şekilde işlendiği bilinmektedir. Anılan uzuv ve gövde parçaları arasında hareketi yansıtması açısından en önemlisi kollardır. Nitekim disk yüzlü figürinlerin önemli bir kısmında dirsekten kıvrılan kollar ve uzantısı olan ellerin göğüs, bel ya da karın üzerinde durduğu bilinmektedir (Ay Efe, 2006, s. 90, 92).

Kemal Uğurbil koleksiyonunda yer alan disk yüzlü figürinin doğrudan benzeri ya da aynı atölye üretimi olarak değerlendirebileceğimiz bir örneği ile bugüne değin saptanan benzer tip figürinlerde karşılaşılmamaktadır. Buna karşın figürin bir bütün olarak değil de, parça parça incelendiğinde benzerlikler net olarak izlenebilmektedir (Şekil 4). Yüz detayları arasında yer alan derin yivli kaşların benzer örnekleri ile Demircihöyük (Şekil 4a-c) (Bilgi 2012, s. 302, Res. 889, 891, 894) ve Külloba (Şekil 4d) (Ay Efe, 2006, s. 94, Res. 1b-c) örneklerinde karşılaşılmaktadır. Çoğunlukla derin oyuk şeklinde betimlenen göz çukurlarının incelediğimiz örneğimizde tamamen delindiği, yüzün arka kısmında yer alan iri kulaklarda yer alan birer deliği karşılar nitelikte olduğu görülmektedir. Bu özellik de yine disk yüzlü figürinlerde nadir de olsa karşılaştığımız betim özellikleri arasında yer almaktadır. Gözün tamamen delinerek, yüz arkasındaki kulak deliklerini karşıladığı bir örnek Çıkrık'tan bilinmektedir (Şekil 4e) (Bilgi, 1979, Lev.1, Res. 2 ve Aydıngün, 2006, s. 32, Res. 26; Bilgi, 2012, s. 298, Res. 853). Disk biçimli yüzün önemli bir bölümü, kavisli iri bir burunla kaplanmaktadır. Burnun iri yapıda olması disk yüzlü figürinlerin karakteristik özellikleri arasında yer almakla birlikte benzerleriyle Akhisar (Şekil 4f) (Ormerod, 1913, s. 54, Fig. 3; Bilgi, 1979, Lev. I, Res. 1; Bilgi, 2012, s. 296, Res. 852), Çıkrık (Bilgi, 1979, Lev.1, Res. 2; Aydıngün, 2006, s. 32, Res. 26; Bilgi, 2012, s. 298, Res. 853), Demircihöyük (Şekil 4g-h) (Obladen Kauder, 1996, Taf. 120-7; Taf. 1217), Küllüoba (Ay Efe, 2006, s. 94, Res. 1b-c) ve Kanlıgeçit (Şekil 4i) (Karul, 2005, s. 118-119, Abb. 1-2) örneklerinde karşılaşılmaktadır. Figürinin yatay bir oluk ile belirtilen ağız kısmının benzerleri Kusura (Bilgi, 
1979, Lev. II, Res. 3) ve Demircihöyük (Şekil 4k-m) (Bilgi, 1979, Lev. III, Res. 8; Obladen Kauder, 1996, Taf. 121-2, 9, 12) örneklerinden tanınmaktadır.

Figürinin omuz kısmının uç noktaları her iki taraftan keskin bir profil çizmektedir. Benzer örneklerinde çoğunlukla yumuşak ve oval bir geçişle temsil edilen bu ünik durumun bilindiği az sayıda başkaca örnek de bulunmaktadır. Bunlar arasında Akhisar (Ormerod, 1913, 54, Fig. 3; Bilgi, 1979, Lev. I, Res. 1; Bilgi, 2012, s. 296, Res. 852) ve Demircihöyük'ten (Şekil 4n) (Bittel - Otto, 1939, Pl. 14.5; Bilgi, 2012, s. 300, Res. 865) bir örnek sayılabilmektedir. Figürinin her iki omuz-kol birleşim, hem de kolların pazu kemiği olarak tanımlayabileceğimiz noktalarında yer verilen dikine kazıma çizgiler yine disk yüzlü figürinlerde karşılaşılan özellikler arasındadır. Her durumda çıplak betimlendiği belirgin olan figürinler üzerinde yer alan bu biçimdeki çizgilerin olasılıkla dövme olabilecek vücut süslemeleri ile ilgili olduğu düşünülür (Karul, 2005, s. 120). Anılan çizgiler Çıkrık (Bilgi, 1979, Lev.1, Res. 2; Aydıngün, 2006, s. 32, Res. 26; Bilgi, 2012, s. 298, Res. 853), Demircihöyük (Şekil 4o-r) (Obladen Kauder, 1996, Taf. 123-6; Bilgi, 2012, s. 300, Res. 865, 868-869), Kaklık (Şekil 4s) (Bilgi, 2012, s. 301, Res. 874), Şarhöyük (Şekil 4t) (Darga ve diğerleri, 2002, s. 210 ve Bilgi, 2012, s. 300, Res. 864) örneklerinde de yer alır. Benzer noktalarda anılan çizgilerin yatay düzenlenmiş olanları Akhisar (Ormerod, 1913, s. 54, Fig. 3; Bilgi, 1979, Lev. I, Res. 1; Bilgi, 2012, s. 296, Res. 852) ve kap biçiminde oluşturulmuş Afyonkarahisar Müzesi’nden bir örnekte (Şekil 4u) (Bilgi, 2012, s. 309, Res. 922) izlenebilmektedir.

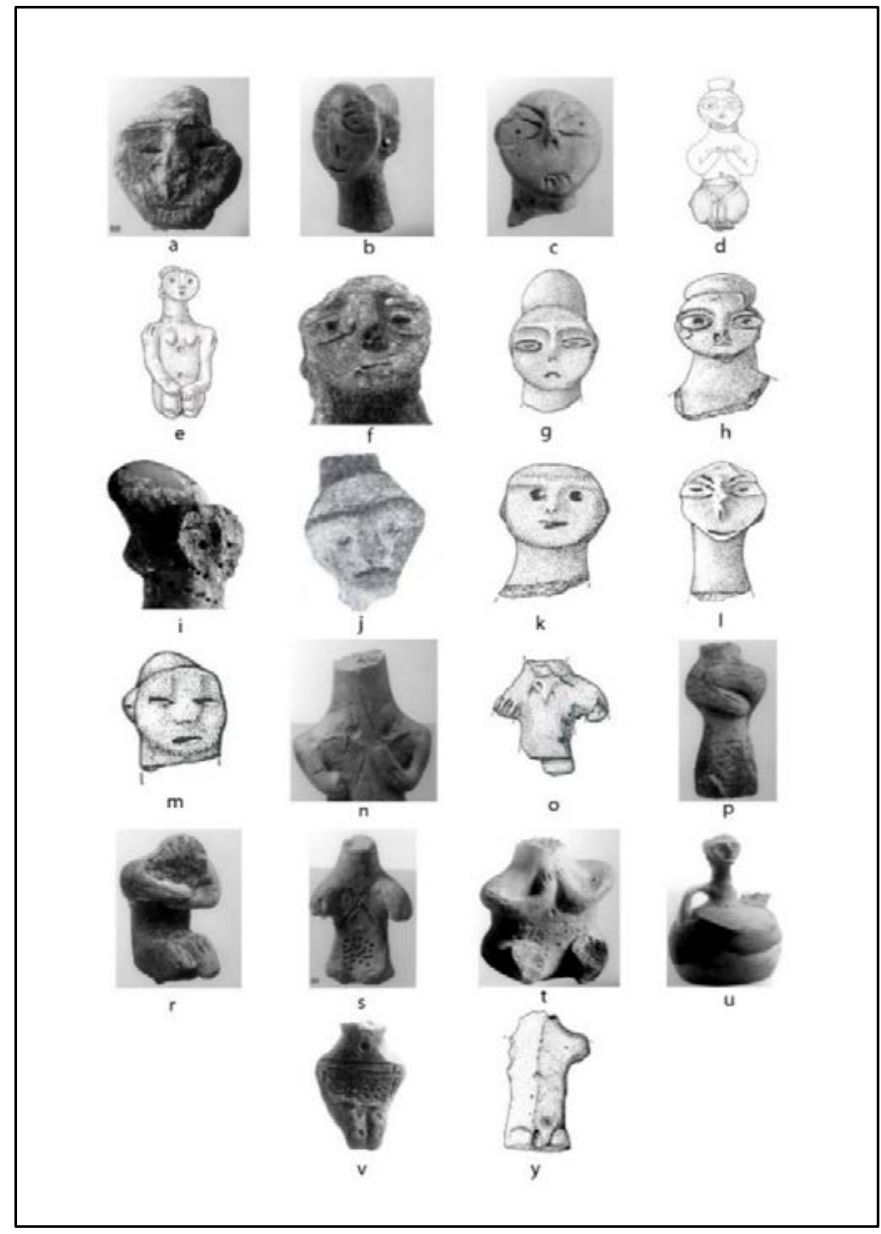

Şekil 4. Metin İçerisinde Karşılaştırma Amaçlı Değerlendirilmiş Merkezlerde Saptanan Disk Yüzlü Figürinler. 
4a: Bilgi, 2012, s. 302, Res. 889; 4b: Bilgi, 2012, s. 302, Res. 891; 4c: Bilgi, 2012, s. 302, Res. 894; 4d: Ay-Efe, 2006, s. 94, Res. 1c; 4e: Bilgi, 1979, Lev. 1, Res. 2; 4f: Ormerod, 1913, s. 54, Fig. 3; 4g: Obladen Kauder, 1996, Taf. 120-7; 4h: Obladen Kauder, 1996, Taf. 120-7, 4i: Karul, 2005, s. 118-119, Abb. 1-2; j: Bilgi, 1979, Lev. II, Res. 3; 4k: Obladen Kauder, 1996, Taf. 121-2; 4l: Obladen Kauder, 1996, Taf. 121-9; 4m: Obladen Kauder, 1996, Taf. 121-12; 4n: Bilgi, 2012, s. 300, Res. 865; 4o: Obladen Kauder, 1996, Taf. 123-6; 4p: Bilgi, 2012, s. 300, Res. 868; 4r: Bilgi, 2012, s. 300, Res. 869; 4s: Bilgi, 2012, s. 301, Res. 874; 4t: Bilgi, 2012, s. 300, Res. 864; 4u: Bilgi, 2012, s. 309, Res. 922; 4v: Bilgi, 2012, s. 297, Res. 862; 4y: Türktüzün ve diğerleri, 2014, s. 59, Res. 19'dan alınarak yeniden düzenlenmiştir.

Figürinin kollarının pozisyonu, var olan tüm örnekler arasında az bilinen bir duruşu sergilemesi açısından dikkat çekicidir. Her ikisi de dirsekten kırık olan kolların yukarıda değindiğimiz üzere soldaki karına, sağdaki ise küçük bir çıkıntı şeklinde belirtilen göğüs kısmına uzanmaktadır. Daha çok her iki kolun da diz, karın ya da gögüs üstünde betimlendiği disk yüzlü figürinler arasında incelediğimiz örneğimize en yakın olanı Demircihöyük'te (Bilgi, 2012, s. 300, Res. 865) tek bir örnekle karşımıza çıkmaktadır. Dizden karın bölgesine çekilmiş, birbirinden bir yivle ayrılmış bacaklar ve karşıya bakar durumda betimlenmiş ayakların duruş pozisyonu itibariyle yaklaşık benzerlerini Akhisar (Ormerod, 1913, s. 54, Fig. 3; Bilgi, 1979, Lev. I, Res. 1; Bilgi, 2012, s. 296, Res. 852), Çıkrık (Bilgi, 1979, Lev.1, Res. 2 ve Aydıngün, 2006, s. 32, Res. 26; Bilgi, 2012, s. 298, Res. 853), Demircihöyük (Şekil 4v) (Bilgi, 2012, s. 297, Res. 862; Bilgi, 2012, s. 300, Res. 869) ve Küllüoba (Ay Efe, 2006, s. 94, Res. 1b-c; Bilgi, 2012, s. 297, Res. 861) örnekleri karşılar niteliktedir. Eserimizin sırt kısmında belirtilen omurga çizgisinin benzer bir örneği Çiledir (Şekil 4y) (Türktüzün ve diğerleri, 2014, s. 59, Res. 19) ve Seyitömer'de (Silek, 2010, s. 48) tespit edilmiştir.

Disk yüzlü figürinlerin Erken Tunç Çağ I sonlarına doğru, yoğun olarak gözlemlendikleri İç Bat1 Anadolu'nun kuzey kesimlerinde yaşam sürdüren toplulukların sosyo-kültürel gelişimlerine paralel olarak üretilmeye başlandıkları belirtilmektedir (Ay Efe, 2006, s. 92). Bu dönemde başlayan söz konusu figürin üretiminin görece dar bir alanda Erken Tunç Çağ II'de de devam ettiği İznik, İnegöl, Eskişehir ve Göller Yöresi'nde saptanan buluntular aracılığıyla doğrulanabilmektedir (Korfmann, 1979, s. 187; Efe, 1992, s. 562). Gelişimin net olarak izlendiği Demircihöyük'te saptanan figürinler üzerine yaptı̆̆ 1 değerlendirmelerde Obladen Kauder, söz konusu figürinlerin F3/G-İ evrelerinden başlayarak bir gelişim izlediğini, yüzün tam disk formunda olmadığı, polosların da belli belirsiz biçimlendirildiği öncül örneklerin (Korfmann, 1979, s. 187; Efe, 1992, s. 562) zamanla gelişerek K, L ve M katlarında daha gerçekçi bir görünüme ulaştı̆̆ını (Korfmann, 1979, s. 187; Efe, 1992, s. 562) bildirmektedir. Bölgede disk yüzlü figürinlerin tespit edildiği Çiledir örnekleri Erken Tunç Çă̆ II tabakasından (Türktüzün ve diğerleri, 2014, s. 52, 58-60), Seyitömer örnekleri ise OTÇ dolgu toprağından ele geçmiştir (Silek, 2010, s. 49). Gövde formu farklı olsa da tipin karakteristik disk yüzlü örneklerini sunan Kanlıgeçit buluntularının, diğer örneklerle paralel olarak Erken Tunç Çă̆ II sonu, III başlarına tarihlenen konutlarda, bölgeye yabancı bazı seramik grupları ile bir arada bulundukları belirtilmektedir (Karul, 2005, s. 117-118).

\section{Değerlendirme}

Figürinler, kullanım ve oluşturma amacı itibariyle arkeoloji bilimi kapsamında farklı yorumlanan arkeolojik eserler arasındadır. Mellart ve Gimbutas'ın öncül çalışmaları (Mellaart, 1967, s. 179; Gimbutas, 1982, 152, s. 237-238) söz konusu eserleri ritüel fonksiyonlar bağlamında hamilelik, bereket gibi anaerkil örgütlenme düzeni üzerinden değerlendirirken, konu ile ilgili son y1llarda oluşturulan çalışmalar, figürin ya da idolleri tanrısal bir varlık olarak tanımlanmasını romantik bir görüş olarak değerlendirmekte (Belcher ve Croucher, 2017, s. 4) ve çoğunlukla bunları insan bedeninin maddeleştirilmesi üzerinden yorumlamaktadır. Bu bağlamda figürin ve idollerin oyuncak (Ucko, 1968; Talalay, 1993; Bailey, 2005), ata soy portreleri (Talalay, 1993 ve Bailey, 2005), koruyucu takılar (Talalay, 1993), adak eşyaları (Bailey, 2005), eğitim objeleri (Ucko, 1968), büyü nesneleri (Ucko, 1968) ve hatta erotik objeler (Düring, 2016, s. 183) olarak da değerlendirildiği bilinmektedir (Mina, 2013, s. 27-28). Bununla beraber, konu bilim dünyasında tartış1lmaya devam etmekte, söz konusu eserlerin çocuk oyuncakları olduğu benzeri düşünceler, toplumsal refahın 
çocuklara böylesine ayrıcalıklı ve maliyetli ürünler sunmak için yeterli olmadığı düşüncesiyle reddedilmektedir (Takaoğlu, 2005, s. 42).

Çalışmamız kapsamında değerlendirdiğimiz disk yüzlü figürinlerin de üretildiği bilinen Erken Tunç Çağ sürecinde söz konusu figürinler ve aynı amaca hizmet eden idollerin buluntu yerleri, bunların işlevsel amaçlardan ziyade dini amaçlarla kullanıldığına dair bilgilerle doludur. Anılan döneme ait bu küçük kült objeleri çoğunlukla doğrudan reenkarnasyon ya da öte dünya inancının izlerini yansıtır şekilde mezarlarda, bazı merkezlerde ise tapınım mekanı olarak tanımlanan yapılar içerisinde ele geçmiştir. Her ne kadar Atakuman'ın değindiği üzere Erken Tunç Çağı öncesi dönemlere ait söz konusu buluntu gruplarının değerlendirilmesi noktasındaki yorum ve tartışmalar, eserlerin köken, kronolojik gelişim, cinsiyet ve anlamı üzerine maddesellik bağlamında oluşturulan sorularına net bir yanıt vermekten uzak ve spekülatif yaklaşımları beraberinde getirse de (Atakuman, 2017, s. 88), yukarıda kısaca değindiğimiz sebepler 1şı̆̆ında ele aldığımız figürinleri de içerisinde barındıran buluntu topluluğuna dönemin dinsel inanışlarının bir ürünü olarak ve tanrıça inancı bağlamında yaklaşmanın daha doğru sonuçlar vereceğini düşünmekteyiz. Nitekim, Anadolu Erken Tunç Çağı ile çağdaş, başta Mezopotamya-Mısır gibi komşu ve yakın bağlantılı bölgelerde yazılı kaynaklarca doğrulanan, başkalaşmış ve bölünerek çoğalmış tanrıça inançlarının varlığı, benzer bir durumun Anadolu için de geçerli olabileceğini düşündürmekte, varlıkları yazılı kaynaklarca kayıt altına alınmış Mezopotamya'da Ninhursag'dan, İnanna'ya, Mısır'da ise Hathor'dan Maat'a yüzlerce ayrı ve farklı işleve sahip olan tanrıçaların varlığı bu noktada dikkat çekmektedir. Aynı zamanda, sınırları şimdilik Afganistan’a kadar dayanan uzak mesafeli geniş bir ticaret ağının varlığı bilinen Erken Tunç Çağ sürecinde Anadolu topluluklarının çevre kültürlerle akültürasyon sürecine girmemiş olduklarını öne sürmek akla yatkın gelmemekte, Erken Tunç Çağ'ın sona ermesini takip eden Anadolu'nun yazılı sürecinde varlığ bilinen pek çok farklı sıfata sahip tanrıçanın bir anda ortaya çıktığını düşünmek de, her dönem bir önceki kültürel sürecin üzerine ekleyerek, eskinin birikimini her daim canlı tutan Anadolu kültürleri açısından gerçekçi görünmemektedir.

Kadın bedenini esas alan figürinler, daha Paleolitik Çağ'dan itibaren arkeoloji literatüründe "Venüs" olarak adlandırılan ilk betim örnekleri aracılığıyla Avrupa'dan Sibirya'ya kadar uzanan ortak inanç birliğinin öznesini oluşturur. Kısa bir süre önce tespit edilen Epi-Paleolitik Dönem, Direkli Mağarası figürin örnekleri, Anadolu'da da tanrıça inancının öncü izlerine örnek sunması açısından son derece önemli sayılmakta (Erek, 2014). İlgili dönemde tanrıçanın doğum ve bereket ile ilişkilendirilen steatopijik yapıda, dolgun vücut hatlarıyla biçimlendirildiği bilinmektedir.

Neolitik çekirdek bölgenin Güney Doğu Anadolu kesiminde gücünü Ata Kültü bağlamında eril tanrısal varlıklarla paylaşmak durumunda kaldığına inanılan (Özdoğan 2007a, s. 441) tanrıçanın, Orta Anadolu, Ege ve G. Doğu Avrupa'ya uzanan Neolitikleşme sürecinde söz konusu bölgelerde yeniden güç kazandığı bilinmektedir. Nitekim bu döneme ait veriler sunan özellikle Çatalhöyük (Mellaart, 1967, s. 178 vd.), Hac1lar (Mellaart, 1970, s. 166-182; Muscarella, 1971, s. 74-79), Höyücek (Duru, 2007, s. 341 ve Duru, 2008, s. 93 vd), Ege Gübre (Sağlamtimur, 2007, s. 375), Ulucak (Çilingiroğlu Derin, Abay, Sağlamtimur ve Kayan, 2004, s. 47-48) ve Pendik (Özdoğan, 2007b, s. 401 vd., Fig. 7) gibi merkezlerde, tanrıçanın inanç sistemi içerisindeki güçlü yerinin kanıtlarını ortaya koyan çok sayıda "dolgun vücutlu tanrıça" betimli buluntu ele geçmiştir.

Neolitik Çağ, tanrıça inancında farklı yorumların, sıfatların da olabileceğini gösteren bir başkalaşım sürecinin ilk izlerini sunması itibariyle de önemlidir. Bu dönemde ilk kez karşılaşılan ve binlerce yıl sürecek bir ikonografinin temelini yansıtan tahtında oturan tanrıçanın (Özdoğan, 2007b, s. 401 vd., Fig. 7) anaerkil bir toplum yapısını, yanındaki yırtıcı hayvanların ise hayvanlara ve doğaya hakimiyeti yansıttığ düşünülebilir. Bununla beraber Çatalhöyük'ten ele geçen ve ön yüzü yaşayan, arkası ise ölümü tanımlar şekilde salt kemik betimlerinden oluşan bir heykelcik (Hodder, 2006, Renkli Şek. 22), olasılıkla reenkarnasyon inancı ile paralel olarak, doğum ve ölümün bir bedende, tanrıçanın kimliğinde yorumlandığını gösterir niteliktedir (Aydıngün, 2006, s. 16; Düring, 2016, s. 110). Çatalhöyük’ten elde edilen bir diğer buluntu bereketle ilişkilendirilen tanrıçanın sırtının oyulduğunu ve bilinçli bir şekilde buraya 
bir tohum tanesinin yerleştirildiğini göstermesi açısından da son derece anlamlıdır (Hodder, 2003). Buna göre tanrıçanın, Paleolitik imgedeki bereket ile ilgili yönü, Neolitik Çağ'da da devam etmektedir ve tanrıçanın bereketli yönü dolgun vücut hatları ve olasılıkla toplumu beslediğine inanılan göğüslerine giden ellerinde, olasılıkla "ana" sıfatıyla simgeleştirilmiş olmalıdır.

Neolitik Çağ'ı takip eden Kalkolitik Çağ'la beraber tanrıça inancı devam etmiş, fakat bu dönemde betim özelliklerinde güçlü değişimler meydana gelmiştir. Geçmişin gerçekçi, natüralist şeması Hacılar gibi merkezler aracılığıyla devam etmekle birlikte, ilgili dönemin içlerinde bir kırılma meydana gelmiş, tanrıça betimleri, seri üretime geçiş sürecinde uzman zanaatkarların elinde şematize bir üslup çerçevesinde işlenmeye başlanmıştır. Kalkolitik Çağ' ’n sonlarında başlayarak yaygınlaşan, kendisini salt figürin değil, aynı zamanda diğer araç ve gereçlerde de gösteren bu durum, olasıllkla nüfus artışına paralel olarak üretim teknolojisinde artan yeni arayışlarının beraberinde getirdiği yeni bir süreç olarak değerlendirilmelidir.

Göller Yöresi’nde Kuruçay (Duru, 2008, s. 142, Res. 279-282) gibi merkezler, hem natüralist, hem de şematize tanrıça örneklerini bir arada sunuyor olması bakımından önemlidir. Nitekim belli bir inanç sistemini takip eder şekilde oluşturulmuş farklı betimler, yukarıda değindiğimiz, olasılıkla tanrıçanın Neolitik Çağ' da görülen başkalaşımının toplum nezdinde tamamen ayrışmaya gittiğini vurgular niteliktedir.

Kalkolitik Çağ'da şematize olmuş tanrıça biçemi salt Anadolu kültürleri ile ilgili değildir. Bu dönemde Güney Levant Bölgesi’nde hakim olan Orta ve Geç Kalkolitik Dönem Ghassulian Kültürü’nün keman biçimli granit idollerinden (Elliott, 1978, s. 46-47, Fig. 5.1), Mezopotamya kökenli, Anadolu’nun özellikle güneydoğusunu da etkisi altına alan Göz İdolleri’ne (Yaylalı, 2014), süreç içerisinde pek çok farklı bölgede tanrıçanın şematize hale gelmiş idol ve figürinleri ile karşılaşılmaktadır. Burada dikkat çekici bir unsur, oldukça geniş bir coğrafyada "her şeyi gören" tanrıça inancını yansıttığına inanılan göz idollerden, sıklıkla gözleri önemsenmeyen Batı Anadolu'nun Kilya figürinlerinde betimlenen tanrıçaya geçişte net bir şekilde izlenen kurgu ve anlamsal farklılıklardır. Her iki grubun da tanrıça inancı ile bir arada değerlendirilmesine karşın gözlemlenen anlam ve betim farkları, yukarıda değindiğimiz ayrımlara güçlü bir örnek sunması açısından da oldukça önemlidir.

Erken Tunç Çağı, Anadolu ve çevresi coğrafyalarda büyük değişimlerin görüldüğü bir dönem olması itibariyle önemlidir. Öncülü Neolitik ve Kalkolitik çağlardan harmanlanarak gelen Anadolu kültürünün devamı niteliğinde gelişen Erken Tunç Çağı sürecinin geniş ticaret ağlarının da oluşmasıyla (Şahoğlu, 2005 ve Efe, 2007) kolektif bir sosyo-kültürel yapılanma şeklinde biçimlendiği söylenebilmektedir. Artan ticaret, beraberinde gelen yeni hammadde arayışları, bu arayışların doğurduğu çıkar çatışmaları ve eril egemen sınıfın yükselişini sağlayan askeri yapılanmaların öncü gelişkin izleriyle de Erken Tunç Çağı'nda karşılaşılmaktadır.

Söz konusu süreçte geçmişten gelen birikimle gücünü yitirmeyen yegane unsurlardan birisinin "tanrıça" inancı olduğu düşünülmektedir. Bu dönemde tanrıça inancı, disk yüzlü figürinlerin de içinde bulunduğu Batı Anadolu'da Ay Efe'nin de belirttiği üzere daha çok figürin ve idol tipleri aracılığıyla takip edilmektedir (Ay Efe, 2006, s. 92). Kalkolitik Çağ'da ortaya çıkan Kilya figürinleri bu dönemde de görülmeye devam etmekte (Collignon, 1901 ve Kamil, 1982, s. 19-20; Takaoğlu, 2005, s. 38), Troia Tipi İdoller, Beycesultan Tipi Keman İdoller, Beycesultan-Kusura Tipi İdoller, Çaykenar Tip İdoller bölgenin ve yakın çevresinin yaygın tanrıça inanç ögeleri arasında değerlendirilen başlıcaları olarak alt gruplarıyla birlikte yer almaktadır (Aydıngün, 2006, s. 29 vd).

Orta Anadolu’da bu dönem Horoztepe (Özgüç, 1958, s. 23-32, 83), Hasanaoğlan (Dolunay, 1960, s. 80) gibi buluntular aracılığıyla net bir şekilde izlenebilen dövme ve döküm tekniği uygulanarak biçimlendirilen maden heykelcikler dikkat çekicidir. Kültepe (Özgüç, 1957 ve Bilgi, 1975), Karaoğlan (Kulaçoğlu, 1992, Res. 92), Etiyokuşu (Kulaçoğlu, 1992, Res. 87), Ahlatlıbel (Koşay, 1934, Fig. 507) ve Koçumbeli (Bilgi, 2012, s. 217, Res. 547) gibi merkezlerde karşılaş1lan idoller, Batı Anadolu benzerleri gibi yaygındır. Bölgenin kuzeyinde, Orta Karadeniz Bölgesi’nde yer alan İkiztepe yerleşiminin sunduğu bulgular, çalışmamızda incelediğimiz disk yüzlü figürinler ile daha paralel örnekler sunması bakımından 
ilgi çekicidir. Burada ele geçen dini amaçlı üretilmiş nesnelerin önemli bir kısmını idollerin değil, figürinlerin oluşturduğu bilinmekte, söz konusu figürinlerin bir kısmının ayakta, bir kısmının ise oturur şekilde betimlendiği bilinmektedir (Gündoğan Aydıngün, 2003, s. 90). Bununla beraber, İkiztepe figürinlerinde gözlemlenen disk biçimli yüz yapısı, disk yüzlü figürinlere ait bir takım karakteristik özelliklerin Orta Karadeniz Bölgesi’nde de var olduğunu göstermesi açısından önemlidir.

Disk yüzlü figürinler ve çağdaşı idol ve figürinlerin önemli bir kısmının kırık bir şekilde ele geçmesi, söz konusu eserlerin kullanım yöntemleri açısından da farklı yorumları beraberinde getirmiştir. Konu hakkında görüş bildiren bilim insanlarından Mellink, Karataş-Semayük Mezarlığı'nda küp mezarlar içerisinde ele geçen mermer idollerin birçoğunda başların kırık olarak bulunmasını, ölümle ilişkili bir ritüelin yansıması olarak değerlendirmektedir (Mellink, 1964, s. 277). Dönemin kırık idol ve figürinlerini ele alan Obladen Kauder, bunların üretildikleri dönemde günlük yaşamda sıkça kullanılan nazarlık benzeri fonksiyonları olabileceğini, bu sebeple yoğun kullanıma bağlı olarak ya da söz konusu eserlerin işgal amaçlı olarak bölgeye ulaşan dış güçlerin bilinçli saldırıları sonucunda tahrip olmuş olabilecekleri düşüncelerini paylaşmaktadır (Obladen Kauder, 1996, s. 257-259).

Daha önce değindiğimiz üzere, disk yüzlü figürinler daha çok adını da aldıkları disk şeklinde biçimlendirilmiş dolgun yüz hatları ile tanınmaktadır. Son derece karakteristik bu yüz yapısının ana ögeleri olarak iri ve bazen delikleri vurgulanmış burun dikkati çekmektedir. Tamamen delinerek açılmış gözleri oval ya da badem formdadır. Ağız kısımları bazı durumlarda dişleri yansıtır şekilde dikey çizgilerle zenginleştirilmiş fakat çoğu zaman yalın bırakılmıştır. Çoğu zaman yalın, az sayıda örnekte açısal yivlerle betimlenen kulakların bazı örneklerde bir veya daha fazla sayıda delikle zenginleştirildikleri bilinir. Kulak ve başın arkasında yer alan polos en az disk biçimli yüz kadar önemli ve bu tip için karakteristik nitelikledir. Az sayıda örnekle ayakta betimlenmiş olanları da tanınmaktaysa da daha çok oturur pozisyonda betimlenen figürinlerin elleri karın, göğüs ya da dizler üzerinde belirtildiği görülmektedir. Bununla beraber çalışmamız içerisinde ele aldığımız örneğimizde olduğu üzere bazı durumlarda iki elin vücudun yukarıda saydığımız farklı uzuvlarına uzandığı figürinler de bulunmaktadır.

Çalışmamız kapsamında incelediğimiz disk yüzlü figürin yukarıda genel şablonunu sunduğumuz benzerleriyle uyum içerisindedir. Figürinin disk biçimli yüz detaylarında dikkat çeken özellikleri arasında yer alan tamamen açılmış gözleri, yüzün arkasında yer alan kulak delikleri ile paralel oluşturulduğunu göstermekte, bu açıdan ilgili figürinin saydığımız boşluklarından ip ya da benzeri bir nesne geçirilerek kullanılmış olabileceğini düşündürmektedir. Bunun yanısıra son derece iri ve içi boş olan gözlerin çağdaş1 Alacahöyük maden heykelciklerinde olduğu üzere değerli taş ya da madenlerle doldurulmuş olabileceği de akla gelmektedir.

Değerlendirmiş olduğumuz figürinin omuz kısmının keskin dönüşü dikkat çekici bir yapıdadır. Her ne kadar disk yüzlü figürinlerde nadir karşılaş1lan bir durum olsa da söz konusu betim özelliğiyle, disk yüzlü figürinlerle çağdaş, literatüre Çaykenar Tip olarak giren figürinlerde sıklıkla karşılaşılmaktadır. Her ne kadar ilk buluntu yeri itibariyle Çaykenar-Antalya Tipi olarak adlandırılsa da söz konusu figürin grubunun anılan bölge dışında sadece Afyon ve yakın coğrafyasında da görüldüğü bilinmekte (Bilgi, 2012, s. 232), bu da disk yüzlü figürin üreticilerinin diğer tip figürinlerden stil yönüyle etkilendiklerini düşündürmektedir. Bunların yanı sıra, disk yüzlü figürinlerin Kiklad etkileri ile oluşturulmuş olabileceğine dair düşünceler bulunmaktaysa da (Bilgi, 1979, s. 135), söz konusu durum Erken Tunç Çağ içerisinde İç Batı Anadolu özelinde değerlendirildiğinde oldukça güç görülmektedir. Nitekim bugünkü veriler 1şığında Anadolu'nun Batı kıyılarında yer alan kültür bölgelerinden iç kısımlara gittikçe Ege etkilerinin azaldığı bilinmektedir. Kısıtlı bir alanda, özellikle Erken Tunç Çağ'ın II-III evrelerinde Orta Anadolu, Kilikya, Suriye ve Mezopotamya ile ilişkili olduğu bilinen İç Batı Anadolu kültür gruplarına ait merkezlerde başta Urfirnis ya da Kiklad Tavaları gibi seramik formları olmak üzere Kiklad Kültürü'ne ait diğer arkeolojik materyallerle karş1laşı1mıyor oluşu, yukarıda savunduğumuz düşünceyi destekler niteliktedir. 
Disk yüzlü figürinlerin de kullanım gördüğü Erken Tunç Çağı'nda farklı tip figürin ve idollerin mezarlık (Kamil, 1985, Fig. 84, s. 289-292; Topbaş ve diğerleri, 1998, s. 66, Fig. 68), tapınak (LloydMellaart, 1962, s. 269) ya da bazen hane içerisinde aynı alanda bir arada ele geçen örnekleri (Kadish, 1971, s. 131; Joukowsky, 1986, s. 90-93), ayrı sıfatlara sahip tanrıçalara eş zamanlı tapınımın varlığına dair bir kanıt olarak değerlendirilebilir. Bu açıdan örneklerini mesnevi dinlerin ortaya çıkış sürecine kadar var olan hemen tüm kültürlerde hem arkeolojik eserler, hem de yazılı kaynaklar aracılığıyla net olarak bildiğimiz politeist yaklaşımın Anadolu'da henüz yazının kullanılmadığı Kalkolitik Çağ içerisinde oluştuğunu ve Erken Tunç Çağı’nda güç kazandığını düşünmemek için bir sebep bulunmamaktadır.

\section{Sonuç}

Disk yüzlü figürinlerin, bu isimle anılmalarına sebep olan yüz biçimlerinden belki de daha önemli özelliği, çalışmamız kapsamında incelediğimiz örneğimizin de bileşenleri arasında yer alan poloslarıdır. Geç dönemlerde tanrıçanın "kentlerin koruyucusu" sıfatı ile ilişkilendirilen polosların düşünsel birlik içerisinde Erken Tunç Çağ toplumları açısından da benzer nitelikte oluşturulmuş olduğu düşünülebilmektedir. Söz konusu figürinlerin sunduğu bu anlatı, sonraki binyıllarda da kabul görmüş olmalı ki, Hitit İmparatorluk Dönemi'nde Hepat, Geç Hitit'te Kubaba, Frig'de Mater'ın, aynı düşüncenin yansıması niteliğinde, başlarında yüksekçe poloslarla betimlendikleri bilinmektedir. Bu ikonografik birliktelik zamanla Anadolu kültürleri ile akültürasyon sürecine giren Grek ve daha sonra Roma'da ana tanrıça kültlerine doğrudan aktarılmaya devam etmiştir. Bu bakımdan disk yüzlü figürinler, binlerce yıllık Anadolu kültür birikimi ve düşün ortaklığının öncül örneklerinden birisi olması ve söz konusu dönemi takip eden çağlarda karşımıza net bir şekilde tanrıça ikonografisinde yansıtılan bir imge ile betimlenmesi itibariyle de son derece önemlidir. Bununla beraber, çalışmamız içerisinde incelediğimiz örneğimizin kollarının bir eli karnında, diğer eli göğsünde şeklinde betimlenen duruş pozisyonu bize göre Anadolu'da binlerce yıl boyunca "bereket ve doğum" ile ilişkilendirilen kadın bedenine da atıf yapar nitelikte, tek bedende iki sıfatlı tanrıçayı yansıtır şekildedir. Eksenellik kavramı ile ilişkilendirebileceğimiz bu durum, özellikle Demir Çă̆ Anadolusu'nun İÖ 1200 göçleri neticesinde sı̆̆ınılan tanrıçası Mater'in imgesinde tekrar vücut bulmuş, tanrıça yüksekçe polosu ve çoğu zaman gülümseyen, "anaç" yüzü ile geçmişin bu köklü birikimini yansıtmaya devam etmiştir.

Satın alma yoluyla kazandırılmış müze ya da özel koleksiyon eserlerinin tarihlendirilmesi, herhangi stratigrafik bir sonuç sunmamaları itibariyle son derece zordur. Bu sebeple çalışmamız içerisinde değerlendirdiğimiz disk yüzlü figürin için keskin bir tarihleme yapma olanağımız bulunmamaktadır. Buna karşın incelediğimiz eserin İç Batı Anadolu yerleşimlerinde sürdürülmüş kazılar neticesinde elde edilen benzerleri, çalışmamız kapsamında değindiğimiz üzere eserimizin Erken Tunç Çağ II içlerine tarihlenebileceğini düşündürmektedir.

\section{Kaynakça}

Atakuman, Ç. (2017). Figurines of the Anatolian Early Bronze Age: the Assemblage from Koçumbeli-Ankara. Anatolian Studies, 67, 85-108.

Ay Efe, D. Ş. M. (2006). Küllüoba'da bulunmuş olan pişmiş toprak figürinlerden birkaç örnek. B. Avunç (Ed.), Hayat Erkanal'a Armağan. Kültürlerin Yansımasl/Studies in Honor of Hayat Erkanal. Cultural Reflections içinde (ss. 90-94). İstanbul: Ege Yayınlar1.

Aydıngün, Ş. (2006). Kentleşme ve tuncun keşfi: İlk Tunç Çağı'nın kutsal bedenleri. Ş. Şentürk, Ş. Aydıngün (Ed.), Tunç Çağı'nın Gizemli Kadınları Sergi Kataloğu içinde (ss. 29-80). İstanbul: Yapı Kredi Yayınları.

Bailey, D. W. (2005). Prehistoric figurines: Representation and corporeality in the Neolithic. London: Routledge.

Belcher, E., ve Croucher, K. (2017). Prehistoric figurines in Anatolia (Turkey). T. Insoll (Ed.), The Oxford Handbook of Prehistoric Figurines içinde (ss. 443-469).

Bilgi, Ö. (1975). Kültepe kazılarında bulunmuş olan insan figürinleri/Antropomorphic representations from the mound of Kültepe. Belleten, 39, 201-208. 
Bilgi, Ö. (1979). MÖ 3. Bin yılına tarihlenen bir grup insan figürini ve bunların Anadolu'da dağılışı. Anadolu Araştırmaları, 6, 133-144.

Bilgi, Ö. (2012). Anadolu'da insan görüntüleri: Klasik Çağ öncesi. İstanbul: Aygaz.

Bittel, K., ve Otto, H. (1939). Demirci Hüyük: Eine vorgeschichtliche siedlung an der phrygisch-bithynischen grenze. Berlin: DAII.

Collignon, M. (1901). Note sur les Fouilles de M. Paul Gaudin Dans la Nécropole de Yortan en Mysie. Comptes Rendus Desséances de l'Académie des Inscriptions et Belles-Lettres, 45, 810-817.

Çilingiroğlu, A., Derin, Z., Abay, E., Sağlamtimur, H. ve Kayan, İ. (2004). Ulucak Höyük: Excavations conducted between 19952002. Louvain: Peeters.

Darga, M, A., Sivas, T. ve Sivas, H. (2002). 2000 yılı Şarhöyük-Dorylaion kazıları. KST, 23 (2), 207-219.

Dolunay, N. (1960). Hasanoğlan idolü. Türk Tarih Kongresi, V, 80-86.

Duru, R. (2007). Göller bölgesi Neolitiği: Hacılar, Kuruçay Höyüğü, Höyücek, Bademağacı Höyüğü. M. Özdoğan, N. Başgelen (Ed.), Türkiye'de Neolitik Dönem: Anadolu'da Uygarlığın Doğuşu ve Avrupa'ya Yayılımı içinde (ss. 331-361). İstanbul: Arkeoloji ve Sanat.

Duru, R. (2008). MÖ 8000'den MÖ 2000'e Burdur-Antalya bölgesinin altı bin yılı. İstanbul: AKMED.

Düring, B. (2016). Küçük Asya'nın tarihöncesi: Karmaşık avcl-toplayıcılardan erken kentsel toplumlara. İstanbul: KU Yayınları.

Efe, T. (1992). 1990 yılında Kütahya, Bilecik ve Eskişehir illerinde yapılan yüzey araştırmaları. AST, 9, 561-585.

Efe, T. (2007). The theories of the 'Great Caravan Route' between Cilicia and Troy: The Early Bronze Age III period in Inland Western Anatolia. Anatolian Studies, 57, 47-64.

Elliott, C. (1978). The Ghassulian culture in Palestine: Origins, influences and abandonment. Levant, 10, 37-54.

Erdoğan, A. (2003). Phokaia Kaya Tapınakları. (Doktora tezi). Ege Üniversitesi, İzmir.

Erek, C. M. (2014). Direkli Cave: The significance of fire and female figurines in the paleo-landscape during the Epi-paleolithic period. Seleucia ad Calycadnum, 4, 151-163.

Gimbutas, M. (1982). The Goddesses and Gods of Old Europe. Los Angeles: University of California Press.

Gündoğan Aydıngün, Ş. (2003). Eski Tunç Çă̆ı Anadolu pişmiş toprak figürin ve idolleri. (Doktora tezi). Hacettepe Üniversitesi, Ankara.

Gür, B., ve Erdan, E. (2018). Batı Anadolu kökenli bir grup erken Tunç Çağı Gaga Ağızlı Testi. Cedrus VI, 125-138.

Hodder, I. (2005). The lady and the seed: Some thoughts on the role of agriculture in the "Neolithic Revolution”. M. Özdoğan, H. Hauptmann, N. Başgelen (Ed.), Köyden Kente Yakındoğu'da İlk Yerleşimler-From Village To Cities Early Villages in the Near East içinde (ss. 129-141). İstanbul: Arkeoloji ve Sanat.

Hodder, I. (2006). Çatalhöyük Leoparın öyküsü: Türkiye’nin kadim “Kasaba”sının gizemleri günışı̆̆ına çıkıyor. İstanbul: Yap1 Kredi Yayınları.

Joukowsky, M. S. (1986). Prehistoric aphrodisias I. Louvain.

Kadish, B. (1971). Excavations of Prehistoric Remains at Aphrodisias, 1968 and 1969. AJA, 75/2, 121-140.

Kamil, T. (1982). Yortan Cemetery in the Early Bronze Age of Western Anatolia. London: BAR.

Karul, N. (2005). Anatolische idole in Ostthrakien: Kırklareli-Kanlıgeçit. B. Terzan, R. Jung, E. Kaiser, B. Horejs (Ed.), Interpretationsraum Bronzezeit, Festschrift für Bernhard Hänsel. Universtätsforschungen zur prähistorischen Archäologie 121 içinde (ss. 117-121). Bonn: Habelt Verlag.

Korfmann, M. (1979). Eine weibliche Göttheit in der Frühbronzezeit Anatoliens. PZ, 54, 187-200.

Koşay, H. Z. (1934). Ahlatlıbel hafriyatı raporu. Türk Arkeoloji ve Etnografya Dergisi, 2, 3-100.

Körte, A. (1899). Kleienasiatische studien IV: Ein altphrygischer Tumulus bei Bos-Öjük (Lamunia). Athenische Mitteilungen, 24, 1-45.

Kulaçoğlu, B. (1922). Tanrılar ve tanrıçalar. Ankara: Kültür ve Turizm Bakanlığı Yayınları.

Mellaart, J. (1967). Çatal Hüyük: A Neolithic town in Anatolia. New York: McGraw-Hill.

Mellaart, J. (1970). Excavations at Hacilar. Edinburgh: Aberdeen University Press.

Mellink, M. J. (1964). Excavations at Karataş-Semayük in Lycia. 1963 AJA, 68, 269-278.

Mina, M. (2013). Anthropomorphic figurines from the Neolithic and Early Bronze Age Aegean gender Dynamics and implications for the understanding of Aegean Prehistory.

Muscarella, O. W. (1971). Hacilar Ladies: Old and new. The Metropolitan Museum of Art Bulletin: New Series, 30, 74-79.

Obladen Kauder, J. (1996). Demircihüyük IV. die kleinfunde. B. die kleinfunde aus ton, knochen und metal. Mainz: Philipp Von Zabern.

Ormerod, H. A. (1913). Prehistoric remains in South-Western Asia Minor III. The Annual of the British School at Athens, 19, 4860. 
Özdoğan, M. (2007a). Bazı genellemeler-öngörüler. M. Özdoğan, N. Başgelen (Ed.), Türkiye'de Neolitik Dönem: Anadolu’da Uygarlı̆̆ın Doğuşu ve Avrupa'ya Yayılımı içinde (ss. 441-458). İstanbul: Arkeoloji ve Sanat.

Özdoğan, M. (2007b). Marmara Bölgesi Neolitik Çağ kültürleri. M. Özdoğan, N. Başgelen (Ed.), Türkiye'de Neolitik Dönem: Anadolu'da Uygarlı̆̆ın Doğuşu ve Avrupa'ya Yayılımı içinde (ss. 401-427). İstanbul: Arkeoloji ve Sanat.

Özgüç, N. (1957). Kültepe kazılarında bulunan mermer idol ve heykelcikler. Belleten, 21, 61-70.

Özgüç, T. (1958). The statuette from İkiztepe. Anadolu/Anatolia, 3, 53-56.

Sağlamtimur, H. (2007). Ege Gübre Neolitik Yerleşimi. M. Özdoğan, N. Başgelen (Ed.), Türkiye'de Neolitik Dönem: Anadolu'da Uygarlığın Doğuşu ve Avrupa'ya Yayılımı içinde (ss. 373-377). İstanbul: Arkeoloji ve Sanat.

Silek, S. (2010). Seyitömer Höyük idolleri. (Yüksek lisans tezi). Dumlupınar Üniversitesi: Kütahya.

Şahoğlu, V. (2005). The Anatolian trade network and the Izmir Region During the Early Bronze Age. Oxford Journal of Archaeology, 24 (4), 339-360.

Takaoğlu, A. (2005). Chalcolithic marble workshop at Kulaksizlar in Western Anatolia: an analysis of production and craft specialization. Oxford: BAR.

Talalay, L. E. (1993). Deities, dolls, and devices: Neolithic figurines from Franchthi Cave, Greece. Bloomington \& Indianapolis: Indiana University Press.

Topbaş, A., Efe, T. ve İlaslı, A. (1998). Salvage excavations of the Afyon Archaeological Museum, Part 2: The Settlement of Karaoğlan Mevkii and the Early Bronze Age Cemetery of Kakl1k Mevkii. Anatolica Antique, 6, 21-94.

Türktüzün, M., Ünan, S. ve Ünal, S. (2014). Çiledir Höyük Erken Tunç Çă̆ı II bulguları. Tüba-Ar, 17, 49-73.

Ucko, P. J. (1968). Anthropomorphic figurines: Of Predynastic Egypt and Neolithic Crete with comparative material from the prehistoric Near East and Mainland Greece. London: Andrew Schmidla.

Yaylalı, S. (2014). Göz İdolleri ve Pirot Höyük Örneği. Cedrus, 2, 1-24. 